\title{
Increased inspired oxygen concentration as a factor in improved brain tissue oxygenation and tissue lactate levels after severe human head injury
}

\section{Matthias Menzel, M.D., Egon M. R. Doppenberg, M.D., Alois Zauner, M.D., Jens Soukup, M.D., Michael M. Reinert, M.D., and Ross Bullock, M.D., Ph.D.}

Division of Neurosurgery, Medical College of Virginia, Virginia Commonwealth University, Richmond, Virginia; and Department of Anesthesiology and Critical Care, Martin Luther University, Halle-Wittenberg, Germany

Object. Early impairment of cerebral blood flow in patients with severe head injury correlates with poor brain tissue $\mathrm{O}_{2}$ delivery and may be an important cause of ischemic brain damage. The purpose of this study was to measure cerebral tissue $\mathrm{PO}_{2}$, lactate, and glucose in patients after severe head injury to determine the effect of increased tissue $\mathrm{O}_{2}$ achieved by increasing the fraction of inspired oxygen $\left(\mathrm{FiO}_{2}\right)$.

Methods. In addition to standard monitoring of intracranial pressure and cerebral perfusion pressure, the authors continuously measured brain tissue $\mathrm{PO}_{2}, \mathrm{PCO}_{2}, \mathrm{pH}$, and temperature in 22 patients with severe head injury. Microdialysis was performed to analyze lactate and glucose levels. In one cohort of 12 patients, the $\mathrm{PaO}_{2}$ ) was increased to $441 \pm 88 \mathrm{~mm} \mathrm{Hg}$ over a period of 6 hours by raising the $\mathrm{FiO}_{2}$ from $35 \pm 5 \%$ to $100 \%$ in two stages. The results were analyzed and compared with the findings in a control cohort of 12 patients who received standard respiratory therapy (mean $\mathrm{PaO}_{2} 136.4 \pm 22.1 \mathrm{~mm} \mathrm{Hg}$ ).

The mean brain $\mathrm{PO}_{2}$ levels increased in the $\mathrm{O}_{2}$-treated patients up to $359 \pm 39 \%$ of the baseline level during the 6-hour $\mathrm{FiO}_{2}$ enhancement period, whereas the mean dialysate lactate levels decreased by $40 \%$ $(\mathrm{p}<0.05)$. During this $\mathrm{O}_{2}$ enhancement period, glucose levels in brain tissue demonstrated a heterogeneous course. None of the monitored parameters in the control cohort showed significant variations during the entire observation period.

Conclusions. Markedly elevated lactate levels in brain tissue are common after severe head injury. Increasing $\mathrm{PaO}_{2}$ to higher levels than necessary to saturate hemoglobin, as performed in the $\mathrm{O}_{2}$-treated cohort, appears to improve the $\mathrm{O}_{2}$ supply in brain tissue. During the early period after severe head injury, increased lactate levels in brain tissue were reduced by increasing $\mathrm{FiO}_{2}$. This may imply a shift to aerobic metabolism.

Key Words * brain metabolism * brain tissue oxygenation * glucose * head injury $*$ hyperoxia * lactate 
Secondary cerebral ischemia resulting in secondary brain damage is one of the major factors influencing prognosis and outcome in patients with severe head injury.[4,50,55] Histopathological examination of the brain tissue in 80 to $90 \%$ of the patients who die shows ischemic damage.[21,22] In animal models and human studies it has been shown that this ischemia is partly caused by a severe reduction in cerebral blood flow (CBF). Such a reduction during the very early period after the primary injury affects approximately $35 \%$ of patients with severe head injury and is worse in patients with brain swelling and subdural hematoma.[4,5,14,37,42] At the same time, the metabolic needs of injured brain tissue seem to be increased in this early phase. Glucose use may be a major source of energy-rich phosphate (adenosine triphosphate) production in neuronal tissue and is markedly stimulated in the early phase after primary brain injury. It may be followed by a severe reduction in glycolysis 7 to 10 days later.[3,31,62] This metabolic activation is at least in part caused by the need to restore ionic homeostasis immediately after the cerebral impact.[7,15,28,31,48] Bergsneider, et al.,[3] have demonstrated in an elegant positron emission tomography study in humans that increased glycolysis after severe head injury affects 30 to $40 \%$ of patients and is both locally adjacent to cerebral lesions as well as global in some cases. This has also been shown in animal models.[26,62]

When both phenomena (CBF reduction and metabolic stimulation) appear together, the result is a flow/metabolism mismatch. A concomitant increase in lactate in brain tissue, which is very common after severe head injury, probably indicates a shift from aerobic to anaerobic metabolic pathways in the neurons and astrocytes and may signify this flow/metabolism mismatch.[1,20,55,57] These processes may precede the delayed events of neuronal death, either by necrosis or possibly by apoptosis in certain circumstances.[26,47,55,57,65]

Recently, this knowledge about the pathogenesis of delayed secondary brain injury has led to attempts to establish better monitoring methods in patients to provide information about substrate delivery and the metabolic status of injured brain tissue. Over the last 2 years we and others have accumulated considerable experience in measuring brain $\mathrm{O}_{2}$ delivery, using new microsensor technology combining a Clark $\mathrm{PO}_{2}$ electrode, with $\mathrm{CO}_{2}, \mathrm{pH}$, and temperature sensors in a single $0.5 \times 25-\mathrm{mm}$ fiber. We have shown that low brain tissue $\mathrm{PO}_{2}$ occurs in approximately 25 to $30 \%$ of patients with severe head trauma in the first 12 hours postinjury. Low brain tissue $\mathrm{PO}_{2}$ also closely correlates with low regional CBF.[18] Recently, we have combined microdialysis, using a 10 X 1-mm flexible probe with the multiparameter sensor to provide detailed, semicontinuous comprehensive local metabolic and substrate monitoring in focal zones of cerebral tissue. $[17,18,64,65]$ This system has allowed us to measure brain $\mathrm{PO}_{2}, \mathrm{PCO}_{2}, \mathrm{pH}$, and lactate and glucose in extracellular fluid in approximately 60 patients.

We have shown that during the 1 st day posttrauma, brain $\mathrm{PO}_{2}$ is frequently lower when compared with measurements obtained on subsequent days and is strongly correlated with high levels of dialysate lactate in the brain. We have therefore speculated that therapies that increase brain $\mathrm{PO}_{2}$ immediately after severe head injury may be beneficial and may also lower local dialysate fluid lactate.[64] Increasing the concentration of inspired $\mathrm{O}_{2}\left(\mathrm{FiO}_{2}\right)$ to $100 \%$ during artificial ventilation has been reported to induce a rise in brain $\mathrm{PO}_{2}$ values, both in animal studies and in humans.[44,53,58] The aim of our study was therefore to measure tissue oxygenation and brain dialysate lactate and glucose levels during the early period after severe head injury in patients who were treated according to a standard protocol of normoxia and normocapnia and to compare these levels with readings in patients to whom a period of supernormal 
normobaric arterial $\mathrm{O}_{2}$ tensions was administered at $1 \mathrm{~atm}\left(\mathrm{FiO}_{2} 100 \%\right)$.

\section{CLINICAL MATERIAL AND METHODS}

\section{Patient Population}

These studies were approved by the Committee for Conduct of Human Research of the Medical College of Virginia (MCV) and Virginia Commonwealth University. Twenty-four patients older than 16 years of age who were admitted to the neuroscience intensive care unit (ICU) at MCV with severe head injury and a Glasgow Coma Scale (GCS) score of 8 or less were included in this study (Table 1). Informed consent for the studies was given by a relative prior to microdialysis. We excluded patients for whom consent could not be obtained, those who were brain dead or close to brain death at admission, and those with lung contusion or pneumonia.

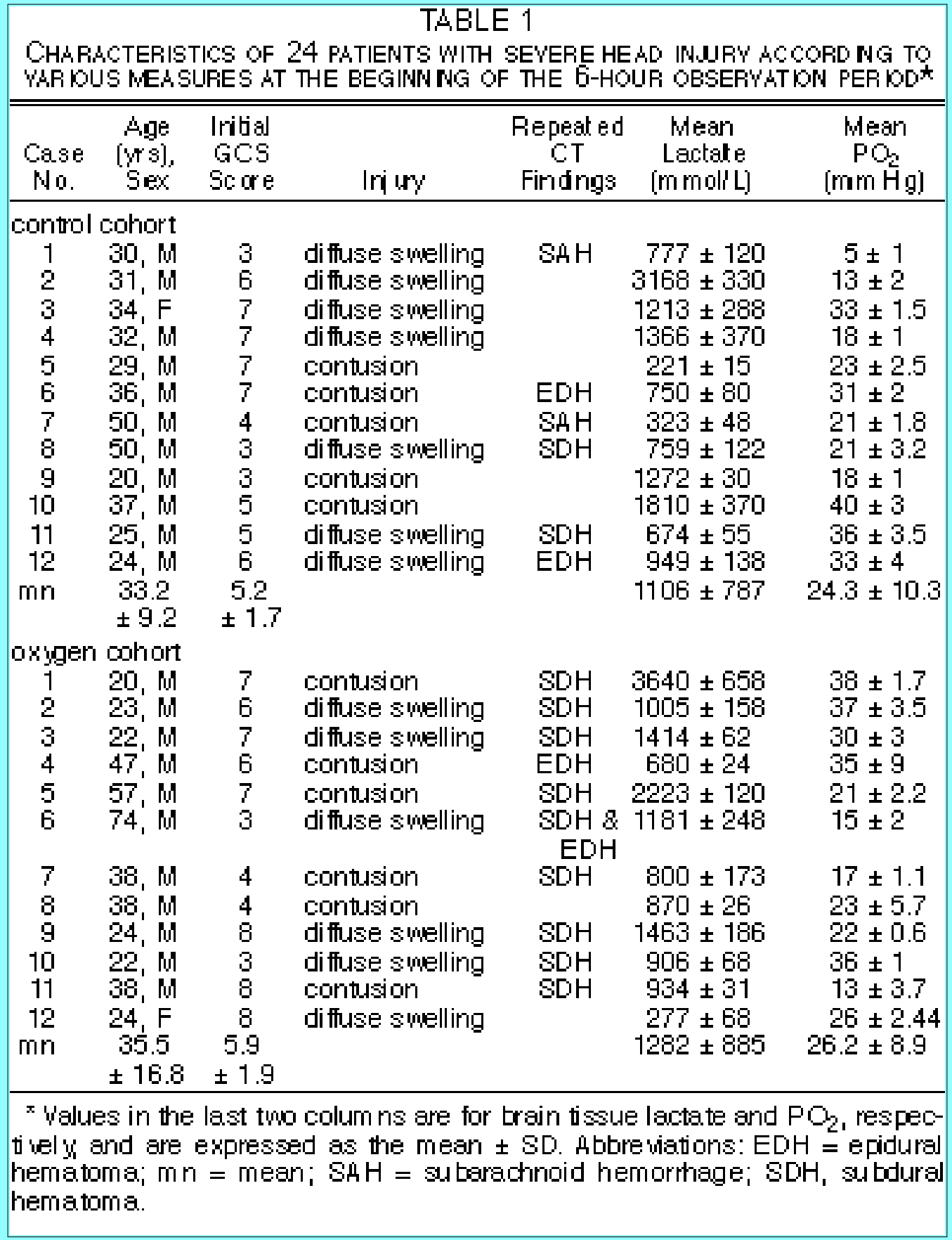


All patients were mechanically ventilated during the entire study period and underwent a ventriculostomy for intracranial pressure (ICP) monitoring. They received intensive cerebral perfusion pressure (CPP)-directed management that emphasized prevention of secondary cerebral insults and prompt evacuation of mass lesions, according to a standard protocol developed at MCV.

Twelve patients were selected as a control cohort; they were treated according to our standard management protocol and underwent cerebral microdialysis. The other 12 patients received a 6-hour administration of supernormal increased arterial $\mathrm{O}_{2}$ concentration within the first 24 hours after admission to the hospital. Both patient cohorts were closely matched. The factors used to determine the matching of the groups included age, gender, initial GCS scores, average ICP and CPP levels, initial levels of dialysate lactate and glucose, brain $\mathrm{PO}_{2}$ values, and the time of initiation of the $\mathrm{FiO}_{2}$ protocol postinjury.

\section{Physiological Parameters}

The patients received a local anesthetic and a triple-lumen transcranial bolt was threaded and tapped into the frontal skull by using a 7-mm twist drill hole, either when the patient arrived in the ICU or in the operating room after evacuation of a hematoma, as described by Zauner, et al.[65] The bolt was used to grip and immobilize the ventricular catheter, the microdialysis probe, and the multiparameter sensor.

Monitoring of ICP. A frontal ventriculostomy was performed to measure the ICP by using a commercial ventriculostomy system and external strain gauge sensor.

Continuous Brain $\mathrm{PO}_{2}, \mathrm{PCO}_{\mathbf{2}}, \mathbf{p H}$, and Temperature Monitoring. A multiparameter, minimally invasive 0.5 X 35-mm sensor was used for continuous measurements of brain tissue $\mathrm{PO}_{2}, \mathrm{PCO}_{2}, \mathrm{pH}$, and temperature. The device consists of two modified optical fibers for $\mathrm{pH}$ and $\mathrm{PCO}_{2}$ measurements, a miniaturized Clark electrode for $\mathrm{PO}_{2}$ measurements, and a thermocouple. The sensor is packaged within a tonometer containing buffer solution, which maintains its hydration and serves as a calibration medium. Before insertion into the patient, the sensor was calibrated with sterile, precision gases bubbled in sequence through the tonometer chamber under microprocessor control. The accuracy and precision of the sensor have been validated in previous in vitro and in vivo studies prior to intracranial use in humans.[41,59,63]

\section{Microdialysis Technique}

A custom-built 10-mm flexible microdialysis probe with an external diameter of $0.5 \mathrm{~mm}$ and a molecular weight cut-off of 20,000 D was sterilized in ethylene oxide. The probe was then inserted into the cortex along with the multisensor. The microdialysis probe was perfused at $2 \mu \mathrm{l} /$ minute by using sterile $0.9 \%$ saline. Sixty-microliter dialysates were collected every 30 minutes into sealed glass tubes by using a refrigerated $\left(4^{\circ} \mathrm{C}\right)$ automated collector system. The microdialysis probe was saved after removal for in vitro calibration. Analyte recovery rates were found to be approximately $35 \%$ for glucose and $42 \%$ for lactate. Glucose and lactate from the collected dialysate were measured offline by using an enzymatic technique.

\section{Patient Groups and $\mathrm{FiO}_{2}$ Protocol}

Control Cohort. Immediately after admission to the ICU a standard protocol of respiratory therapy was administered to the patients and kept constant during the entire observation period. This protocol is 
aimed at keeping the $\mathrm{FiO}_{2}$ sufficient to establish a $\mathrm{PaO}_{2}$ of approximately 100 to $150 \mathrm{~mm} \mathrm{Hg}$. These $\mathrm{PaO}_{2}$ levels are generally considered to establish normoxic arterial conditions. Thus, 98 to $100 \%$ arterial hemoglobin saturation with $\mathrm{O}_{2}$ can be achieved routinely. The $\mathrm{PaCO}_{2}$ was kept between 28 and $34 \mathrm{~mm}$ $\mathrm{Hg}$.

Arterial oxygenation and $\mathrm{CO}_{2}$ status were monitored continuously by peripheral pulse oximetry (for peripheral hemoglobin saturation of $\mathrm{O}_{2}$ ) and end-tidal $\mathrm{CO}_{2}$ measurement. Additionally, arterial blood was drawn via a radial arterial catheter and blood gas levels were assessed hourly during the 6-hour observation period.

Oxygen Cohort. Within the first 18 hours after admission to the ICU, standardized $\mathrm{PaO}_{2}$ enhancement was performed in two stages. The protocol was started as soon as the multimodal monitoring was established and at least 3 hours after stable values were obtained in continuous brain tissue $\mathrm{PO}_{2}$ monitoring.

First, we determined the necessary $\mathrm{FiO}_{2}$ to achieve a $\mathrm{PaO}_{2}$ of approximately $130 \mathrm{~mm} \mathrm{Hg}$ in each individual. The respiratory settings were then kept constant over a baseline period of 4 hours. The $\mathrm{PaCO}_{2}$ was kept between 28 and $34 \mathrm{~mm} \mathrm{Hg}$ for all patients during these studies. In a second step, we increased the $\mathrm{FiO}_{2}$ to $60 \%$ for 3 hours. In a third step, $\mathrm{FiO}_{2}$ was further increased to $100 \%$, again for 3 hours. At the end of this observation period the $\mathrm{FiO}_{2}$ was reduced to the individual baseline level.

\section{Statistical Analysis}

The ICP, mean arterial blood pressure, end-tidal $\mathrm{CO}_{2}$, and peripheral hemoglobin saturation of $\mathrm{O}_{2}$ were continuously measured and automatically collected every 3 seconds from the bedside ICU monitors into a VAX mainframe computer. The automatically recorded data included brain $\mathrm{PO}_{2}, \mathrm{PCO}_{2}, \mathrm{pH}$, and temperature and were downloaded every 5 minutes into a Macintosh personal computer. The intermittent hourly results (dialysate lactate, dialysate glucose, $\mathrm{FiO}_{2}$, and clinical events) were then time-locked and added to the software template. The continuously measured data were smoothed by rejecting obviously outlying points and the mean values over each 30-minute interval were calculated.

Commercially available statistical software was used. For comparisons between the characteristic data in both patient cohorts, analyses of variance (ANOVAs) and descriptive statistics were used.[54] Linear Pearson's correlation ( $\mathrm{r}$ values), logistic linear regression ( $\mathrm{R}$ values), paired comparisons, and nonparametric tests (Spearman's rank correlation) were also used. For calculating the mean values of the linear correlation coefficients, a Fisher Z-transformation of the individual $r$ values was used. All values are expressed as the mean \pm standard deviation (SD) if not otherwise indicated.

Oxygen Cohort. For analysis we divided the entire observation period into two sections. The first 4 hours of constant ventilation were regarded as the baseline period. The mean values of brain lactate, glucose, and $\mathrm{PO}_{2}, \mathrm{PCO}_{2}$, and $\mathrm{pH}$ were calculated and used as baseline levels (100\%). The following 6 hours ( 2 X 3 hours) of increased $\mathrm{FiO}_{2}$ up to $60 \%$ and $100 \%$ were regarded as the enhancement period.

Control Cohort. After establishment of the stable multimodality monitoring, and after 3 hours, a time period was chosen that showed stable results for continuous brain $\mathrm{PO}_{2}, \mathrm{PCO}_{2}$, and $\mathrm{pH}$ monitoring. The 
changes in the monitored parameters in all individuals of both cohorts were used for statistical analyses to determine significant differences during the 6-hour observation period.

\section{Sources of Supplies and Equipment}

The external strain gauge sensor was acquired from Codman, Randolph, MA, and the Paratrend 7/Neurotrend microsensors were purchased from Diametrics Medical, Inc., Roseville, MN. The flexible microdialysis and the CMA 170 automated collector system were obtained from CMA Microdialysis, Acton, MA. The measurements of the glucose and lactate dialysates were performed using a model YSI 2700 Select device purchased from Yellow Springs Instruments Co., Inc., Yellow Springs, OH. The Macintosh personal computer was acquired from Apple Computers, Inc., Cupertino, CA. The StatView version 4.1 statistical software was obtained from Abacus Concepts, Berkeley, CA.

\section{RESULTS}

\section{Cohort Characteristic Data}

The characteristic data for both patient cohorts in this report are shown in Tables 1 and 2. The initial GCS scores for 22 of the patients ranged from 3 to 8 . Two patients of the $\mathrm{O}_{2}$ cohort had a GCS score of 10 at the time of admission, deteriorated into a coma during the first 6 hours after admission, and were subsequently monitored using the multimodal system. In total, 17 of the 24 enrolled patients underwent a craniotomy for hematoma removal. The ANOVAs revealed no significant differences between the characteristic data of the two cohorts except for the brain glucose results (Table 2).

\begin{tabular}{|c|c|c|}
\hline \multicolumn{3}{|c|}{$\begin{array}{l}\text { TABLE } 2 \\
\text { COMPARISON OF YAR WUS FACTORS MEA SURED IN BRAN } \\
\text { TISSUE AT THE BEGINN NG OF THE OBSERYATION PER IOD } \\
\text { IN } 24 \text { PATIENTS WITH SEVERE HEAD INURY }\end{array}$} \\
\hline Factor & $\begin{array}{c}\text { Cortrol } \\
\text { (12 patients) }\end{array}$ & $\begin{array}{c}\text { Oxygen } \\
\text { (12 paibents) }\end{array}$ \\
\hline $\begin{array}{l}\text { start (hrs) } \\
\text { IOP (mm Hg) } \\
\mathrm{CPP}(\mathrm{mm} \mathrm{Hg}) \\
\mathrm{PaO}_{2}(\mathrm{~mm} \mathrm{Hg}) \\
\mathrm{pH} \\
\mathrm{PCO}_{2}(\mathrm{~mm} \mathrm{Hg}) \\
\text { gluose }(\mu \mathrm{mol} h)\end{array}$ & $\begin{array}{c}12.1 \pm 7.0 \\
19 \pm 9 \\
80 \pm 21 \\
136 \pm 22 \\
6.97 \pm 0.36 \\
57.2 \pm 5.9 \\
941 \pm 477\end{array}$ & $\begin{array}{c}11.9 \pm 6.9 \\
15 \pm 5 \\
73 \pm 16 \\
121 \pm 30 \\
7.02 \pm 0.33 \\
88.0 \pm 114.8 \\
559 \pm 392 \dagger\end{array}$ \\
\hline \multicolumn{3}{|c|}{$\begin{array}{l}\approx \text { Start }=\text { interval between admission and start of the } \\
\text { observation period. } \\
t \text { Statistically significant according to unpaired t-test ( } p \text { < } \\
0.05 \text { ). }\end{array}$} \\
\hline
\end{tabular}

\section{Control Cohort}

During the 6-hour analysis period, no significant variations of $\mathrm{PaO}_{2}$ were observed to result from the $\mathrm{FiO}_{2}$ management. At the beginning, the mean $\mathrm{PaO}_{2}$ was $136.4 \pm 22.1 \mathrm{~mm} \mathrm{Hg}$ compared with $154.2 \pm$ $31.8 \mathrm{~mm} \mathrm{Hg}$ at the end of the study period. The mean brain $\mathrm{PO}_{2}$ increased slightly during this time, from $24.3 \pm 10.3$ to $29.8 \pm 16 \mathrm{~mm} \mathrm{Hg}$ ( $p>0.05$; Fig. 1 upper left). A statistically significant correlation existed between brain $\mathrm{PO}_{2}$ and $\mathrm{CPP}(\mathrm{r}=0.34 ; \mathrm{p}<0.001)$. The parameters ICP, $\mathrm{CPP}, \mathrm{PCO}_{2}$, and $\mathrm{pH}$ showed no significant variations within the time period of observation. 

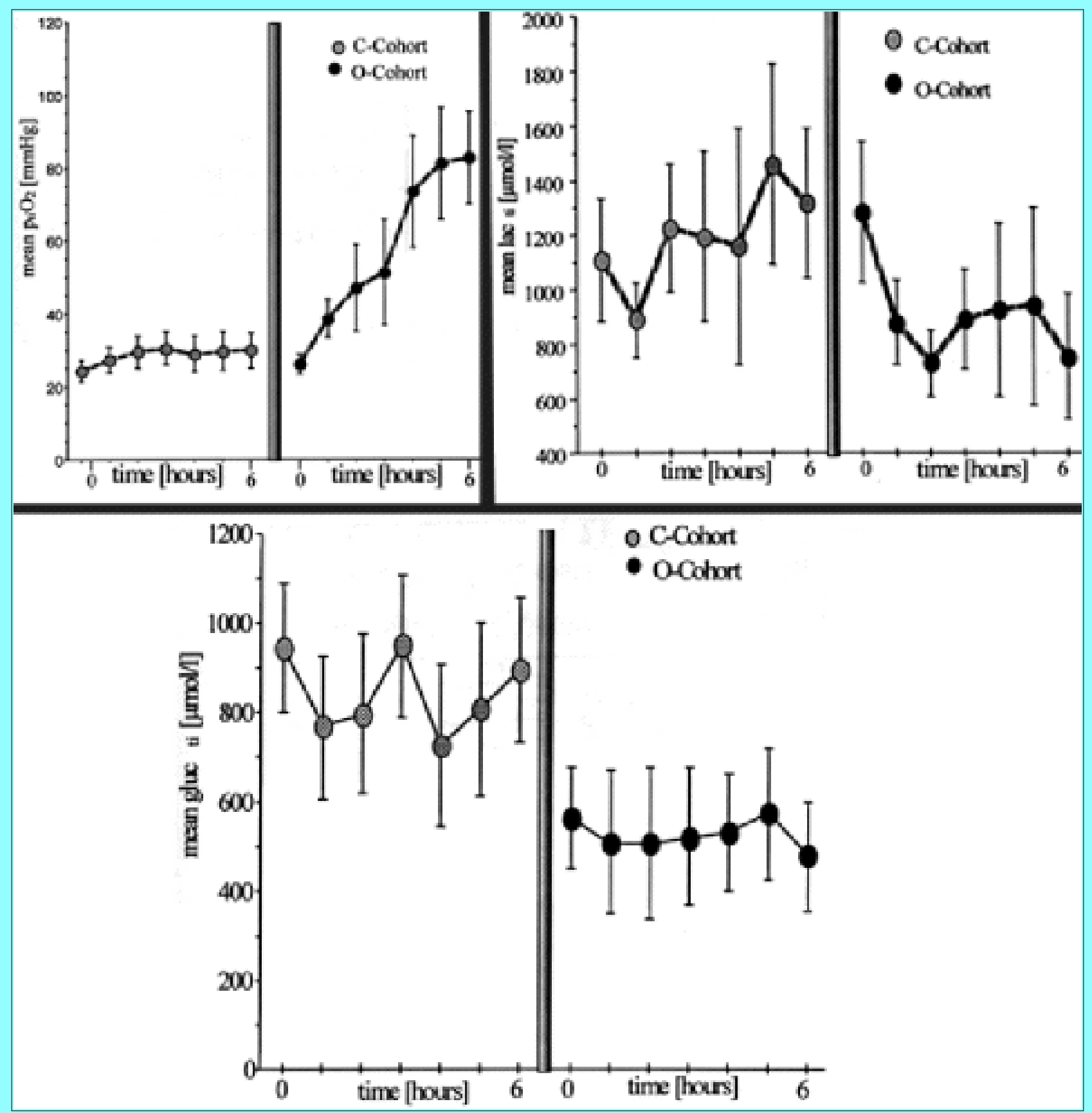

Fig. 1. Graphs showing the time course of mean brain tissue $\mathrm{PO}_{2}\left(\left[\right.\right.$ mean $\left.\mathrm{p}_{\mathrm{ti}} \mathrm{O}_{2}\right]$ upper left), mean brain tissue lactate ([mean lac $\left.{ }_{\mathrm{ti}}\right]$ upper right), and mean brain tissue glucose ([mean gluc $\left._{\mathrm{ti}}\right]$ lower), in 12 patients each in the control (C-Cohort) and the $\mathrm{O}_{2}$-treated cohort (O-Cohort). Error bars indicate the standard error of the mean.

The mean brain lactate measured by the microdialysis probe remained high during the entire study period: $1106.8 \pm 787$ at the beginning, rising to $1319.6 \pm 948.7 \mu \mathrm{mol} / \mathrm{L}$ at the end (Fig. 1 upper right). Statistical analyses revealed no significant correlation between ICP, CPP, or $\mathrm{PaO}_{2}$ and lactate. The time course of the mean brain glucose values is given in Fig. 1 lower. At the end of the observation period we found a mean glucose level of $844.3 \pm 543.1 \mu \mathrm{mol} / \mathrm{L}$ compared with $941 \pm 477.7 \mu \mathrm{mol} / \mathrm{L}$ at the start. When we tested the correlation between brain lactate and $\mathrm{pH}$ there was no significant relationship. In contrast, brain $\mathrm{pH}$ and $\mathrm{PCO}_{2}$ showed a significant inverse correlation $(\mathrm{r}=-0.4 ; \mathrm{p}<0.0 .001)$. 
Baseline Period. The mean $\mathrm{PaO}_{2}$ was $121.4 \pm 30 \mathrm{~mm} \mathrm{Hg}$ over the entire baseline period, the mean $\mathrm{PaCO}_{2}$ was $32 \pm 4 \mathrm{~mm} \mathrm{Hg}$, and the $\mathrm{pH}$ of the arterial blood was $7.44 \pm 0.05$. The peripheral hemoglobin saturation measured by pulse oximetry ranged between $98 \%$ and $100 \%$. The mean values of brain lactate and $\mathrm{PO}_{2}$, measured during the initial baseline observation period, are given for each patient in Table 1 . Dialysate lactate ranged from 277 to $3640 \mu \mathrm{mol} / \mathrm{L}$ (mean lactate $1282 \pm 885 \mu \mathrm{mol} / \mathrm{L}$ ). Dialysate glucose ranged from 118 to $1370 \mu \mathrm{mol} / \mathrm{L}$ (mean glucose $412 \pm 358 \mu \mathrm{mol} / \mathrm{L}$ ). The lowest brain $\mathrm{PO}_{2}$ level was 13.2 $\mathrm{mm} \mathrm{Hg}$ and the highest was $38 \mathrm{~mm} \mathrm{Hg}$ (mean $\mathrm{PO}_{2} 26.2 \pm 8.9 \mathrm{~mm} \mathrm{Hg}$ ) on an $\mathrm{FiO}_{2}$ of $35 \pm 5 \%$. Brain lactate and $\mathrm{PO}_{2}$ showed no close relationship during this period.

The mean values of ICP, CPP, $\mathrm{pH}$, and $\mathrm{PCO}_{2}$ are summarized in Table 2. Analysis of the correlation between brain $\mathrm{pH}$ and lactate within the 12 individuals showed no significant inverse relationship $(\mathrm{r}=$ $-0.33 ; p>0.05)$. These findings were consistent with those seen in the control cohort.

Oxygen Enhancement Period. Analyses of the time course of CPP and ICP revealed no significant variations during the 6 hours. The mean ICP at the end of the study period was $13.2 \pm 2.7 \mathrm{~mm} \mathrm{Hg}$ compared with $15 \pm 5 \mathrm{~mm} \mathrm{Hg}$ at the beginning of the experiment. The mean CPP was found to be $77.9 \pm$ $13.5 \mathrm{~mm} \mathrm{Hg}$ compared with $73 \pm 16 \mathrm{~mm} \mathrm{Hg}$.

Brain Tissue Oxygen Levels. Increasing $\mathrm{FiO}_{2}$ to $60 \%$ resulted in an increase in the $\mathrm{PaO}_{2}$ in all patients (mean $\mathrm{PaO}_{2} 240.1 \pm 57.2 \mathrm{~mm} \mathrm{Hg}$ ). At $100 \% \mathrm{FiO}_{2}, \mathrm{PaO}_{2}$ increased further to $441.2 \pm 88.2 \mathrm{~mm} \mathrm{Hg}$ ). This represents a $264 \%$ increase in the mean $\mathrm{PaO}_{2}$ during $100 \% \mathrm{FiO}_{2}$ ventilation.

The brain $\mathrm{PO}_{2}$ increased in each patient, as did the $\mathrm{PaO}_{2}(\mathrm{R}=0.36 ; \mathrm{p}<0.05)$. At $60 \% \mathrm{FiO}_{2}$ the percentage change was increased by $109 \pm 90 \%$ of the baseline value, and at $100 \% \mathrm{FiO}_{2}$ the mean $\mathrm{PO}_{2}$ increased by $259 \pm 39 \%$ compared with the baseline (Fig. 1 upper left). Thus, in this cohort the mean brain $\mathrm{PO}_{2}$ was found to be $82.7 \pm 44.1 \mathrm{~mm} \mathrm{Hg}$.

However, analyses of the individual patients revealed a broad heterogeneity in the $\mathrm{PO}_{2}$ response to the induced changes of the $\mathrm{PaO}_{2}$. Two illustrative cases of patients with different clinical situations are given in Figs. 2 and 3. These indicate a different time course for individual $\mathrm{PO}_{2}$ values. 


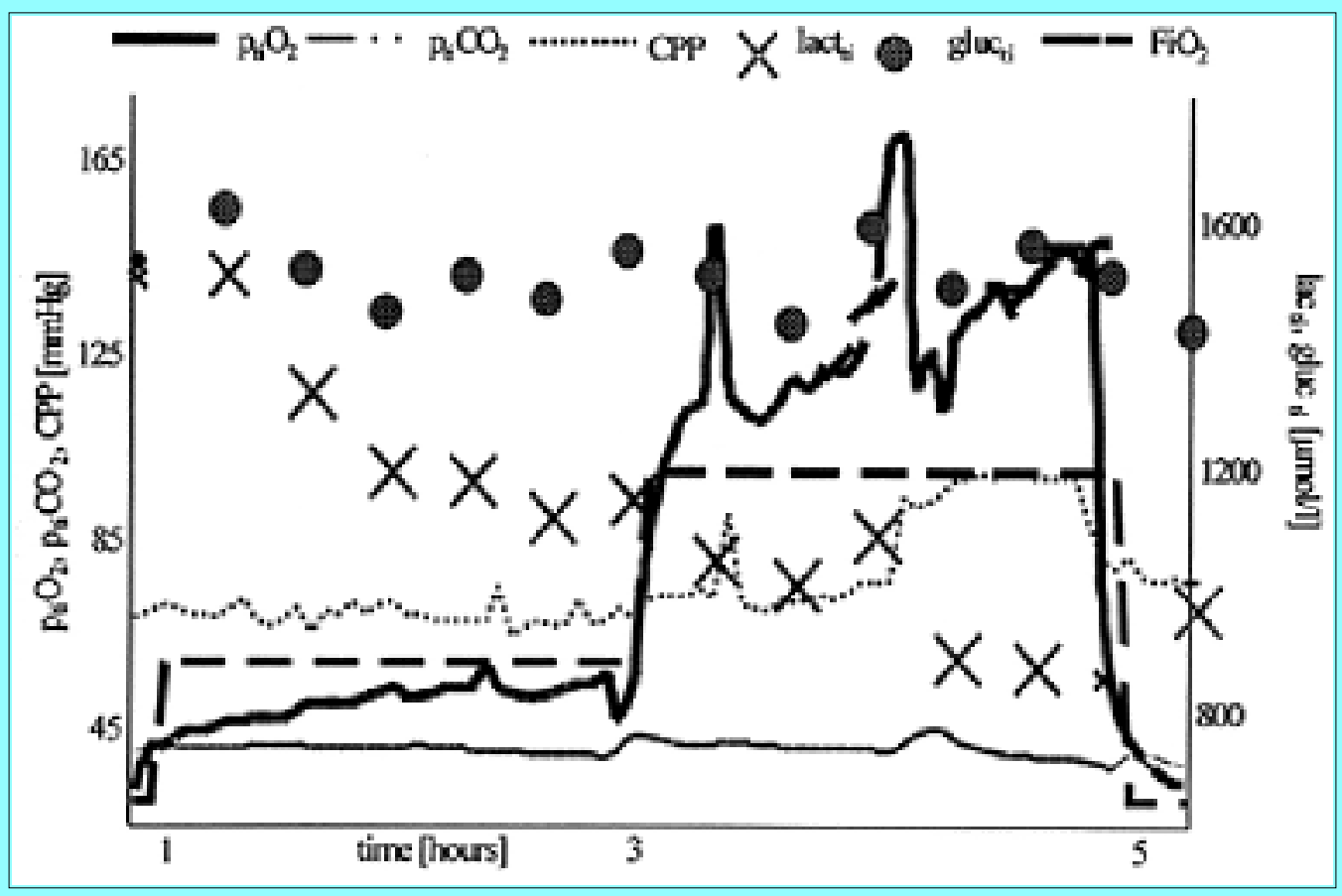

Fig. 2. Case 3. Graph showing the time course of mean brain tissue $\mathrm{PO}_{2}\left(\mathrm{p}_{\mathrm{ti}} \mathrm{O}_{2}\right)$, brain tissue $\mathrm{PCO}_{2}\left(\mathrm{p}_{\mathrm{ti}} \mathrm{CO}_{2}\right), \mathrm{CPP}$, dialysate lactate (lact $\mathrm{ti}_{\mathrm{i}}$ ), and glucose ( gluc $\left._{\mathrm{ti}}\right)$ at different $\mathrm{FiO}_{2}$ levels during the enhancement period.

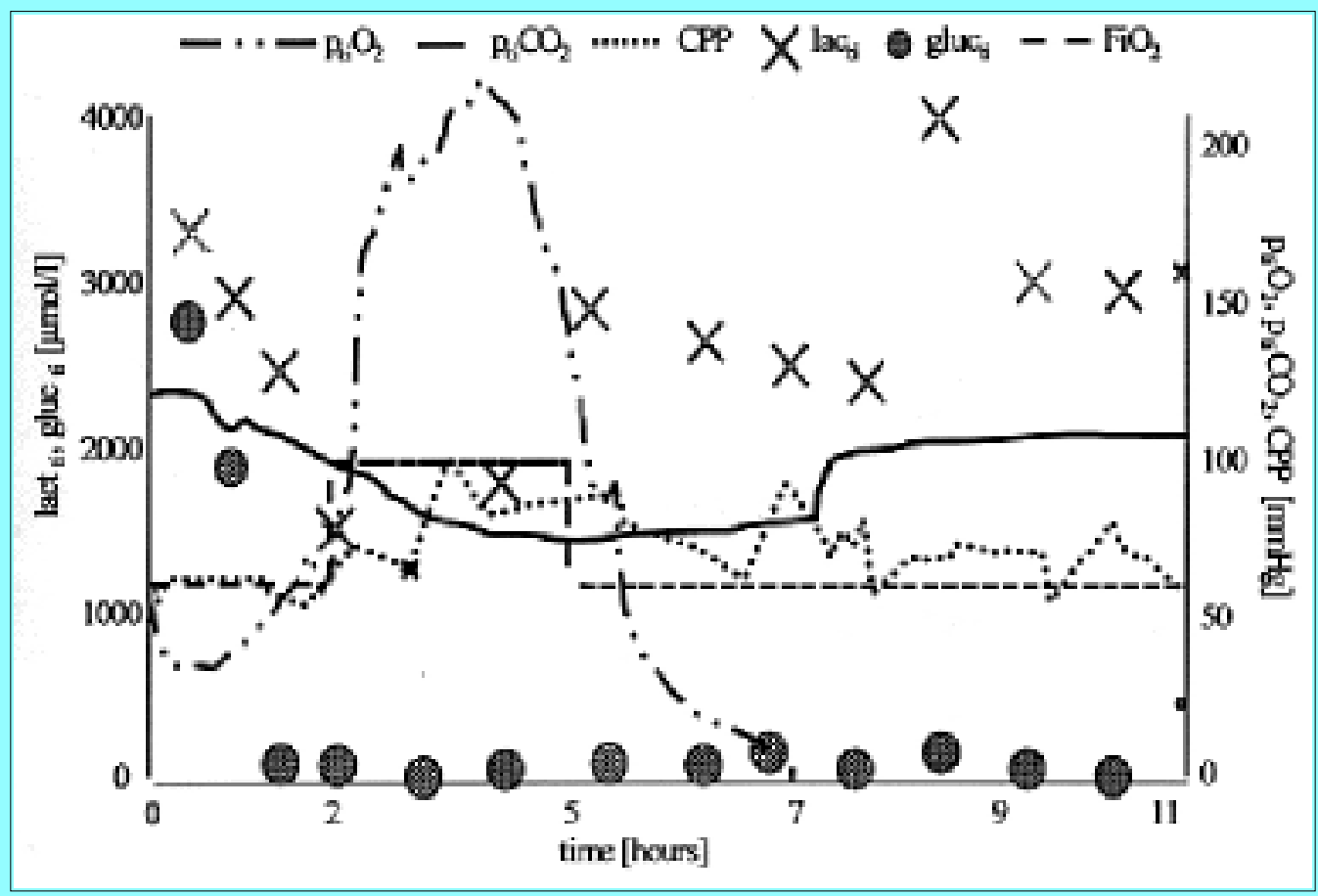

Fig. 3. Case 1. Graph showing the time course of the brain tissue $\mathrm{PCO}_{2}\left(\mathrm{p}_{\mathrm{ti}} \mathrm{CO}_{2}\right), \mathrm{CPP}$, dialysate lactate $\left(\right.$ lact $\left._{\mathrm{ti}}\right)$, and glucose $\left(\mathrm{gluc}_{\mathrm{ti}}\right)$ at different $\mathrm{FiO}_{2}$ levels during the enhancement period.

Lactate Levels. The levels of lactate in the brain decreased during the period of increased $\mathrm{FiO}_{2}$ in proportion to its average value during the baseline period (Fig. 1 upper right). The mean lactate level at the end of the $\mathrm{O}_{2}$ enhancement period was $754 \pm 527 \mu \mathrm{mol} / \mathrm{L}$. This represents a decrease of $40 \%$ ( $\mathrm{p}<$ 0.001 , ANOVA). We found a linear relationship between the percentage change in the brain lactate and 
$\mathrm{PO}_{2}$ values in all individual measurements obtained during the $\mathrm{O}_{2}$ enhancement period $(\mathrm{R}=0.215 ; \mathrm{p}<$ $0.05)$. Figure 4 shows the distribution of the individual coefficients of linear regression between lactate and $\mathrm{PO}_{2}$.

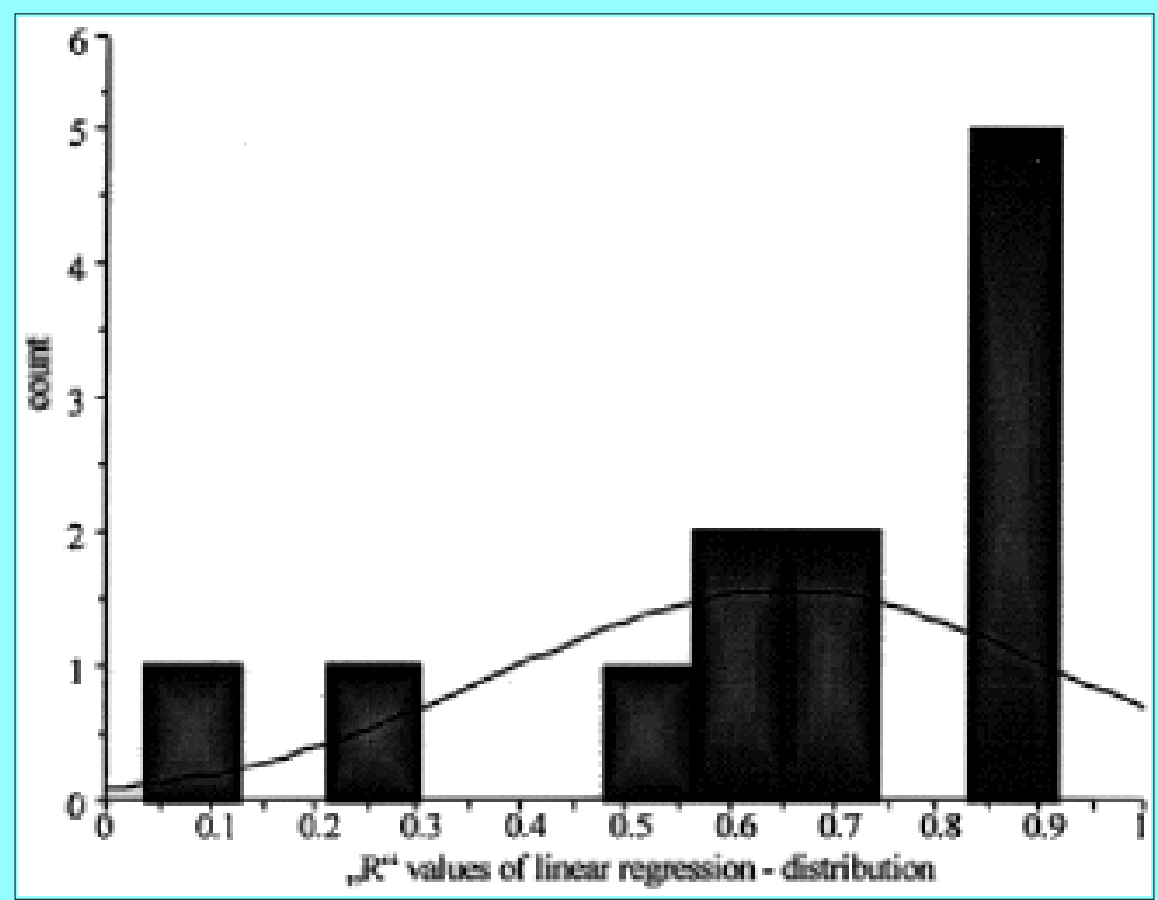

Fig. 4. Histogram showing the individual linear regression $\mathrm{R}$ values between the absolute values of brain tissue lactate and brain tissue $\mathrm{PO}_{2}$ during the $\mathrm{O}_{2}$ enhancement period in the 12 patients in the $\mathrm{O}_{2}$-treated cohort. The mean of the $\mathrm{r}$ value distribution was significantly different from zero (one sample t-test, $\mathrm{p}<0.05$ ).

By using this method of analysis, it is seen that the majority of the individual $\mathrm{R}$ values are located in the range between 0.5 and 0.7 . Tests of the distribution of the individual $\mathrm{R}$ values showed a significant difference of the mean from zero (one sample t-test, $\mathrm{p}<0.05$ ). The linear regression model (Fig. 5) revealed a close relationship between the brain lactate levels and the $\mathrm{pH}$ values during the period of increased $\mathrm{FiO}_{2}\left(\mathrm{R}^{2}=0.61 ; \mathrm{p}<0.001\right)$. 


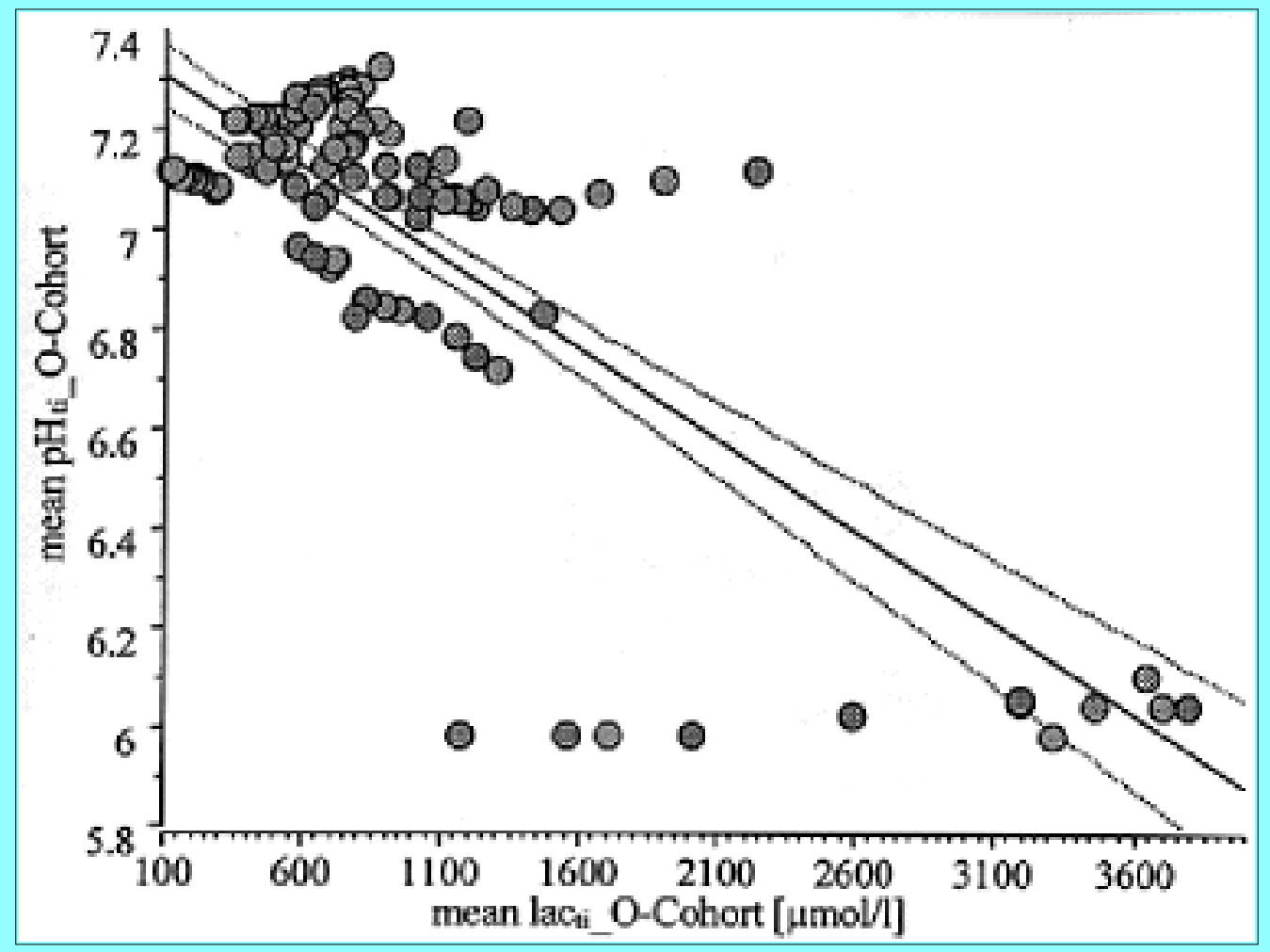

Fig. 5. Scatterplot showing linear regression between the individual brain tissue lactate $\left(\mathrm{lac}_{\mathrm{ti}}\right)$ values and the brain tissue $\mathrm{pH}\left(\mathrm{pH}_{\mathrm{ti}}\right)$ levels of the $\mathrm{O}_{2}$-treated cohort (12 patients) during the $\mathrm{O}_{2}$ enhancement period $\left(\mathrm{r}^{2}=0.613 ; \mathrm{p}<0.001\right)$. The dotted lines indicate the $95 \%$ confidence area.

Glucose Levels. The levels of glucose in the brain showed no clear trend during the $\mathrm{O}_{2}$ enhancement period and seemed not to be influenced by the $\mathrm{O}_{2}$ enhancement maneuver. The heterogeneity of the glucose behavior is demonstrated by the SD at the endpoint of the observation period at $100 \% \mathrm{FiO}_{2}$ (mean glucose $480 \pm 418.6 \mu \mathrm{mol} / \mathrm{L}$ ). Figure 1 lower shows the time course of the mean glucose values in comparison with the glucose of the control cohort. None of the other monitored parameters was significantly related to the time course of the glucose values.

\section{ILLUSTRATIVE CASES}

\section{Case 3}

This 22-year-old man had an initial GCS score of 7 after a motor vehicle accident. His admission computerized tomography (CT) scan revealed diffuse brain swelling and a thin subdural hematoma over the left hemisphere. Eleven hours postinjury, the $\mathrm{O}_{2}$ enhancement period was begun and maintained for 6 hours. The dialysate lactate level was high, and $\mathrm{CPP}, \mathrm{PO}_{2}$, and $\mathrm{PCO}_{2}$ were normal (Fig. 2). An increase in brain $\mathrm{PO}_{2}$ was seen, corresponding to the $\mathrm{FiO}_{2}$ increase. The high $\mathrm{PO}_{2}$ values on $100 \% \mathrm{FiO}_{2}$ showed a broad heterogeneity and were influenced by the course of the CPP. Brain tissue lactate levels decreased during this period and glucose was unaffected. The patient had made a good recovery at the 3-month follow-up visit.

\section{Case 1}

This 20-year-old man was admitted after a motor vehicle accident, with a GCS score of 7. His initial CT 
scan revealed multiple left frontotemporal contusions and a large left-sided subdural hematoma. Before his admission to the ICU, craniotomy was performed and the hematoma was removed. Over the next 48 hours the patient developed uncontrollably high ICP of approximately $40 \mathrm{~mm} \mathrm{Hg}$, and he died depite full therapy with mechanical ventilation, pressors, cerebrospinal fluid drainage, and mannitol administration. The initial brain $\mathrm{PCO}_{2}$ and lactate values were dangerously high. His ICP was initially $20 \mathrm{~mm} \mathrm{Hg}$, and his CPP was less than $70 \mathrm{~mm} \mathrm{Hg}$ before pressor therapy was begun. His brain $\mathrm{PO}_{2}$ was greater than 30 mm Hg. By increasing $\mathrm{FiO}_{2}$ to $100 \%$, a corresponding increase in the $\mathrm{PO}_{2}$ values was seen. However, while the patient was still at $100 \% \mathrm{FiO}_{2}$, his brain $\mathrm{PO}_{2}$ values started to decrease and fell to zero, when $\mathrm{FiO}_{2}$ was reduced to $60 \%$ (Fig. 3). The initial drop in lactate at the start of the $\mathrm{FiO}_{2}$ enhancement reversed simultaneously with a decrease in the $\mathrm{PO}_{2}$ and lactate values, and then climbed again to extremely high levels of more than $3000 \mu \mathrm{mol} / \mathrm{L}$. The brain $\mathrm{PCO}_{2}$ showed the same behavior as lactate. The CPP was inconsistent during this period and most of the time it was close to the threshold level of 60 to $70 \mathrm{~mm} \mathrm{Hg}$, despite maximal pressor therapy.

\section{DISCUSSION}

Cerebral oxygenation is currently monitored in two different ways. The global cerebrovenous $\mathrm{O}_{2}$ measurement in the bulb of the jugular vein is an established method that reflects the relationship between $\mathrm{O}_{2}$ delivery to the brain and the extraction of $\mathrm{O}_{2}$ by the brain.[6,8,50,51] Local brain tissue oximetry by single Clark-type electrodes or multiparameter probes measuring $\mathrm{PO}_{2}, \mathrm{PCO}_{2}, \mathrm{pH}$, and temperature simultaneously in brain tissue is a more recent monitoring method that gives information about substrate delivery and neuronal homeostasis in the locally studied cerebral region, depending on the position in which the measurement probe is placed.[16,19,24,32,44,58,63] The interdependence of the jugular saturation of $\mathrm{O}_{2}$ and $\mathrm{PO}_{2}$ on $\mathrm{CBF}$ has been well demonstrated in several clinical studies.[12,51,58,65]

Only a few reports describe the response of $\mathrm{PO}_{2}$ measurement to the induction of different arterial $\mathrm{O}_{2}$ concentrations.[36,40,44,53,58] In these animal studies brain tissue oxygenation was monitored using different technical approaches in healthy noninjured brains. Van Santbrink, et al.,[58] first described the effect of increasing brain tissue $\mathrm{PO}_{2}$ in patients with severe head injury in response to normobaric hyperoxia induced by mechanical ventilation with $100 \%$ inspiratory $\mathrm{O}_{2}$ over a period of approximately 30 minutes.

This pilot study has shown that increasing the $\mathrm{PaO}_{2}$ to levels higher than needed to fully saturate hemoglobin apparently can increase $\mathrm{PO}_{2}$, epecially when it is low, and that this effect continues over a period of several hours. However, this simple interpretation of our data depends on what exactly the "tissue $\mathrm{O}_{2}$ " probe is measuring. The concomitant reproducible decrease in lactate (40\%) in the $\mathrm{O}_{2}$-treated cohort indicates that the increase in tissue $\mathrm{O}_{2}$ is real, and that it affects oxidative metabolism favorably. This interpretation is supported by the findings in the control cohort of our study. Increased brain tissue lactate levels frequently occur in the early period after severe head injury, during the 1 st day of the trauma. The implications of these findings may be very important, although validation is clearly needed in other centers and in more patients.

\section{Parameter Changes at Normoxic $\mathrm{PaO}_{2}$}


Our findings for brain $\mathrm{PO}_{2}, \mathrm{PCO}_{2}$, and $\mathrm{pH}$ in the control cohort and in the $\mathrm{O}_{2}$ cohort during the baseline period are in accordance with results reported in the literature, in both human studies and animal experiments. $[24,32,44,53,58,63,65]$ The $\mathrm{PO}_{2}$ measurement in both cohorts showed no relationship to the lactate concentrations in brain tissue during constant arterial normoxic conditions. This is consistent with the results of a previous study conducted by our group.[65]

The CPP and ICP levels showed no major influences on the brain tissue measurement results in our study. However, these parameters were rather constant during the observation period, because the patients were all undergoing intensive care treatment, and in the matching of the cohorts we aimed to achieve comparable stable patient populations.

\section{Oxygen Enhancement Period}

Effects on Dialysate Lactate. In our study, brain dialysate lactate decreased during the 6-hour period of increased $\mathrm{PaO}_{2}$ in the $\mathrm{O}_{2}$-treated cohort. This neurochemical finding was significantly correlated with an increase in brain tissue $\mathrm{PO}_{2}$ and $\mathrm{pH}$, as measured by the multiparameter probe. Microdialysis findings in 24 patients after severe head injury, as described previously in a study in which the same microdialysis technique was used,[65] revealed that a dialysate lactate level of greater than $300 \mu \mathrm{mol} / \mathrm{L}$ generally was seen in patients with a poor prognosis after severe head injury.

Under normal conditions, brain lactate output is suppressed in the presence of sufficient $\mathrm{O}_{2} \cdot[1,10,27,33,35]$ The conventional view regarding lactate accumulation claims that oxidative energy metabolism is rendered inoperative, either through substrate $\left(\mathrm{O}_{2}\right)$ unavailability (ischemia) or damage to mitochondria. Lactate is thus the product of a metabolic switch away from the aerobic tricarboxylic acid cycle pathway within the mitochondria to the anaerobic utilization of glucose. Pyruvate is the product of the glycolytic breakdown of glucose. If $\mathrm{O}_{2}$ is lacking, or the transport mechanisms or mitochondria are damaged, pyruvate undergoes anaerobic conversion to lactate by the enzyme lactate dehydrogenase.[33] During this metabolic conversion of lactate the reduced form of nicotinamide adenine dinucleotide is reoxidized to $\mathrm{NAD}^{+}$, which is necessary for the continuation of glucose breakdown into pyruvate. Thus, in the presence of a preserved glucose supply, an $\mathrm{O}_{2}$ delivery/demand mismatch, such as occurs under the condition of incomplete ischemia, causes glycolytic accumulation of lactate in brain tissue to develop.[11] Thus, elevated lactate concentrations in neuronal tissue are considered to indicate an anaerobic metabolic status.[11,27,30,33,43,55]

On the other hand, lactate increase is not only induced by ischemia. Andersen and Marmarou[1] demonstrated increased glycolysis and cerebral acidosis in cats by using a fluid-percussion injury model in nonischemic, normoxic animals. These authors proposed a metabolic compartmentalization of neuronal energy production because of a disparity between the maximal rates of glycolysis and oxidative phosphorylation. Thus, some of the lactate that is present after brain injury may be the result of a normal physiological rather than a pathological response to trauma. Furthermore, elevations in the excitatory neurotransmitter glutamate have been shown to increase lactate production by astrocytes.[47] Thus, increased brain lactate levels may be due to several mechanisms.

It has also been shown recently that neuronal mitochondria show a specific functional deficit that appears to be calcium-mediated after severe head injury.[60] Thus, independent of the actual status of CBF and $\mathrm{O}_{2}$ delivery to the tissue, neuronal mitochondrial perturbation may induce a specific, posttraumatic 
transient impairment of tricarboxylic acid cycle metabolism, leading to a compensatory increase in anaerobic glycolysis. [7,26] Such a posttraumatic mitochondrial perturbation, independent of CBF, could also explain our finding that the brain $\mathrm{PO}_{2}$ levels during normoxic periods in our investigation showed no correlation to the levels of baseline dialysate lactate. However, when $\mathrm{O}_{2}$ availability to these damaged mitochondria is increased, we speculate that their function may be ameliorated by a "mass action" effect of increased $\mathrm{O}_{2}$.

Elevations of cerebral lactate have also been described in head-injured patients experiencing delayed clinical and physiological deterioration. $[7,13,20,37,38,45,48,49,57,65]$ The presence of high levels of lactate in the brain has been shown to be a prognostically relevant factor after severe head injury.[13] Valadka, et al.,[57] reported on six patients suffering from incurable ICP elevation after severe head injury. Their clinical deterioration was accompanied by a significant increase in brain tissue lactate levels. Goodman, et al.,[20] demonstrated that administration of barbiturates to patients after severe head injury influences pathologically high lactate levels.

We speculate that postinjury mitochondrial membrane alterations lead to a partial functional failure of aerobic metabolism. Microvascular failure and intermittent CBF reduction also cause a relatively hypoxic situation. Oxygen flux out of the capillaries into the tissue and subsequently into the neurons and then the mitochondria is impaired by alterations of the compartment interface conditions. Diffusion distances are lengthened because of cytotoxic cell swelling, and arteriovenous shunts may direct CBF away from the capillaries. Thus, an $\mathrm{O}_{2}$ delivery/metabolism mismatch develops after severe head injury. Increasing the driving force of capillary/tissue $\mathrm{O}_{2}$ flux should therefore be an effective measure to push more $\mathrm{O}_{2}$ into the mitochondria. The reduction in tissue lactate, as compared with the baseline levels of the $\mathrm{O}_{2}$-treated patients or to the time course of lactate within the control cohort, indicates that cerebral oxidative energy production resulting from Krebs cycle activity in mitochondria may be increasing following $\mathrm{O}_{2}$ increase, according to our findings.

\section{Cerebral Oxygenation}

The valuable information provided by brain $\mathrm{O}_{2}$ monitoring either in the cerebrovenous blood or in the brain tissue in patients after severe head injury has been extensively

demonstrated.[6,8,12,16,24,32,51,65] As a result, a better understanding of cerebral $\mathrm{O}_{2}$ consumption and metabolic needs in different pathological settings after severe head injury has been achieved. The importance of periods of desaturation of the cerebrovenous blood, as measured by jugular fiberoptic catheters after severe head injury, is an example.[6,8,12,50,51]

More recently, attempts have been made to identify a critical threshold for brain tissue $\mathrm{PO}_{2}$ as measured by Clark electrodes in the brains of patients with severe head injury.[16,18,32,64] Increasing $\mathrm{FiO}_{2}$ in patients at high risk for cerebral $\mathrm{O}_{2}$ deficiency caused by an incomplete saturation of hemoglobin with $\mathrm{O}_{2}$ is a well-established therapy in clinical ICU management of severely head injured patients. The current thinking is that achieving an arterial hemoglobin saturation of $100 \%$ is the upper limit of usefulness. Furthermore, increasing the $\mathrm{FiO}_{2}$ to greater than $40 \%$ in patients with intact respiration, when arterial hemoglobin is completely saturated, results in an increase of only the physiologically dissolved $\mathrm{O}_{2}$ in plasma, which represents only approximately 2 to $3 \%$ of overall $\mathrm{O}_{2}$ transport. The quantitative 
effect of this physically dissolved $\mathrm{O}_{2}$ in blood is small. Thus, an increase of in $\mathrm{PaO}_{2}$ beyond the level necessary for $100 \%$ saturation of hemoglobin has not yet been established as a therapeutic measure to improve cerebral $\mathrm{O}_{2}$ supply.

However, if it is assumed that the results of brain $\mathrm{PO}_{2}$ measurement reflect the actual $\mathrm{O}_{2}$ delivery to the neurons, then our data are mechanistically attractive.[16-18,40,58,65] Recently, several other groups have reported the direct dependence of the brain $\mathrm{PO}_{2}$ levels on the $\mathrm{PaO}_{2} \cdot[44,53,58]$ This relationship was found across a wide range of $\mathrm{PaO}_{2}$ values.

\section{Cerebral $\mathrm{O}_{2}$ Flux After Severe Head Injury}

The physiology of $\mathrm{O}_{2}$ distribution between the peripheral cerebral microvasculature and the brain tissue remains poorly understood. The interface conditions between the different compartments of $\mathrm{O}_{2}$ distribution in the brain and the microvasculature are not yet well described.[29,39] However, meeting actual neuronal tissue energy requirements by maintaining adequate $\mathrm{O}_{2}$ flux is the fundamental requirement of the cerebral $\mathrm{O}_{2}$ exchange apparatus. Thus, the magnitude of $\mathrm{O}_{2}$ flux is the decisive quantity that needs to be maximized when the system is stressed, and capillary $\mathrm{PO}_{2}$ represents the "driving force" that is available for $\mathrm{O}_{2}$ exchange and is the limiting factor on its magnitude. $[9,23,29,59,61]$ Confocal microscopy of rat brain cortex indicates that 10 to $20 \%$ of cerebral capillaries may not contain erythrocytes at any given time.[34,56] Thus, nonhemoglobin $\mathrm{O}_{2}$ transport may be more significant than was previously thought. This assumption is the rationale for various attempts to establish hyperbaric oxygenation as a treatment modality.[2,25,38,52] Holbach, et al.,[25] investigated the effect of hyperbaric $\mathrm{O}_{2}$ treatment on global cerebral lactate metabolism in patients after severe head injury. They demonstrated a reduction of the cerebrovenous lactate concentration in these patients by using 1.5 atm of hyperbaric $\mathrm{O}_{2}$ treatment. Furthermore, increased $\mathrm{FiO}_{2}$ of up to $100 \%$ under normobaric conditions also reduced the cerebrovenous lactate in these patients after severe head injury, as seen in our study.

\section{Clinical Implications}

A simplistic interpretation of these data suggests that ventilation with $100 \% \mathrm{O}_{2}$ should be considered at least for the first 6 to 18 hours after any severe head injury, when metabolic demand on the neuronal energy systems is greatest. Emergency personnel may improve the chances of restoring brain energy homeostasis by using $100 \% \mathrm{O}_{2}$, at least until the patient's condition is stable in the ICU. However, further validation of this study is needed, and it must first be shown that oxidative metabolism, with increased adenosine triphosphate generation, increases as a result of this $\mathrm{O}_{2}$ enhancement in severe head injury.

Our data cannot establish the optimal level of the inspiratory $\mathrm{O}_{2}$ concentration or the duration of increased $\mathrm{FiO}_{2}$ that is most beneficial in individuals with severe head injury. Comparing CBF findings with the achievable response of brain $\mathrm{PO}_{2}$ to changes in $\mathrm{FiO}_{2}$ could provide a better understanding of the relationship between blood flow autoregulation and brain tissue $\mathrm{PO}_{2}$ and $\mathrm{PCO}_{2}$. This could be especially important if one considers the fact that application of $\mathrm{FiO}_{2}$ levels higher than $60 \%$ may be harmful when used for longer than 24 hours in adults.[46] An inflammation of the tracheal surface can occur, and the 
induction of pulmonary atelectases is critically dependent on the application time of the increased $\mathrm{FiO}_{2}$ when it is close to $100 \%$. This results in an increased incidence of pulmonary infections and structural damage to the lungs. Nevertheless, if it can be more widely shown that administration of $100 \% \mathrm{O}_{2}$ to patients with severe head injury can indeed improve cerebral $\mathrm{O}_{2}$ delivery and metabolism during the critical early period, then this simple maneuver may improve outcome.

\section{Acknowledgments}

We are grateful to John J. Woodward, Ph.D., and Beat Alessandri, Ph.D., for help with the high-performance liquid chromatography studies. Additionally, we are grateful to Paula B. Brockenbrough, R.C.P, and Carmen Hennig, M.S., for their support of this study.

\section{References}

1. Andersen BJ, Marmarou A: Functional compartmentalization of energy production in neural tissue. Brain Res 585:190-195, 1992

2. Berg $\varnothing \mathrm{GW}$, Tyssebotn I: Effect of exposure to oxygen at 101 and $150 \mathrm{kPa}$ on the cerebral circulation and oxygen supply in conscious rats. Eur J Appl Physiol 71:475-484, 1995

3. Bergsneider M, Hovda DA, Shalmon E, et al: Cerebral hyperglycolysis following severe traumatic brain injury in humans: a positron emission tomography study. J Neurosurg 86:241-251, 1997

4. Bouma GJ, Muizelaar JP, Choi SC, et al: Cerebral circulation and metabolism after severe traumatic brain injury: the elusive role of ischemia. J Neurosurg 75:685-693, 1991

5. Bouma GJ, Muizelaar JP, Stringer WA, et al: Ultra-early evaluation of regional cerebral blood flow in severely head-injured patients using xenon-enhanced computerized tomography. J Neurosurg 77:360-368, 1992

6. Bullock R, Stewart L, Rafferty C, et al: Continuous monitoring of jugular bulb saturation and the effect of drugs acting on cerebral metabolism. Acta Neurochir Suppl 59:113-118, 1993

7. Bullock R, Zauner A, Tsuji O, et al: Patterns of excitatory amino acid release and ionic flux after severe head trauma, in Tsubokawa T, Marmarou A, Robertson C, et al (eds): Neurochemical Monitoring in the Intensive Care Unit. Tokyo: Springer-Verlag, 1995, pp 64-77

8. Chan KH, Dearden NM, Miller JD: Multimodality monitoring as a guide to the treatment of intracranial hypertension after severe brain injury. Neurosurgery 32:547-553, 1993

9. Chance B, Oshino N, Sugamo T, et al: Basic principles of tissue oxygen determination from mitochondrial signals, in Bicher HI, Bruley DF (eds): Oxygen Transport to Tissue. New York: Plenum, 1973, pp 277-292

10. Cohen RD, Iles RA: Intracellular pH: measurement, control and metabolic interrelationship. CRC Crit Rev Clin Lab Sci 6:101-143, 1975

11. Combs DJ, Dempsey RJ, Maley M, et al: Relationship between plasma glucose, brain lactate, and intracellular pH during cerebral ischemia in gerbils. Stroke 21:936-942, 1990 
12. Cruz J, Miner ME, Allen SJ, et al: Continuous monitoring of cerebral oxygenation in acute brain injury: injection of mannitol during hyperventilation. J Neurosurg 73:725-732, 1990

13. DeSalles AAF, Kontos HA, Becker DP et al: Prognostic significance of ventricular CSF lactic acidosis in severe head injury. J Neurosurg 65:615-624, 1986

14. Dewitt DS, Jenkins LW, Wie EP, et al: Effects of fluid-percussion brain injury on regional cerebral blood flow and pial arteriolar diameter. J Neurosurg 64:787-794, 1986

15. Di X, Harpold T, Watson JC, et al: Excitotoxic damage in neurotrauma. Fact or fiction? Rest Neurol Neurosci 9:231-241, 1996

16. Dings J, Meixensberger J, Amschler J, et al: Brain tissue $\mathrm{pO}_{2}$ in relation to cerebral perfusion pressure, TCD findings and TCD-CO $\mathrm{CO}_{2}$-reactivity after severe head injury. Acta Neurochir 138:425-434, 1996

17. Doppenberg EMR, Rice M, Di X, et al: Increased free radical production due to subdural hematoma in the rat: effect of increased inspired oxygen fraction. J Neurotrauma 15:337-347, 1998

18. Doppenberg EMR, Zauner A, Bullock R, et al: Correlation between brain tissue oxygen tension, carbon dioxide tension, $\mathrm{pH}$ and cerebral blood flow--a better way of monitoring the severely injured brain? Surg Neurol (In press)

19. Globus MY, Busto R, Lin B, et al: Detection of free radical activity during transient global ischemia and recirculation: effects of intraischemic brain temperature modulation. J Neurochem 65:1250-1256, 1995

20. Goodman JC, Valadka AB, Gopinath SP, et al: Lactate and excitatory amino acids measured by microdialysis are decreased by pentobarbital coma in head-injured patients. J Neurotrauma 13:549-556, 1996

21. Graham DI: The pathology of brain ischaemia and possibilities for therapeutical intervention. Br $\mathbf{J}$ Anaesth 57:3-17, 1985

22. Graham DI, Ford I, Adams JH, et al: Ischaemic brain damage is still common in fatal non-missile head injury. J Neurol Neurosurg Psychiatry 52:346-350, 1989

23. Groebe K, Thews G: Basic mechanisms of diffusive and diffusion-related oxygen transport in biological systems: a review, in Erdmann W, Bruley DF (eds): Oxygen Transport to Tissue XVI. New York: Plenum, 1992, pp 277-292

24. Hoffman WE, Charbel FT, Edelman G: Brain tissue oxygen, carbon dioxide, and $\mathrm{pH}$ in neurosurgical patients at risk for ischemia. Anaesth Analg 82:582-586, 1996

25. Holbach KH, Caroli A, Wassmann H: Cerebral energy metabolism in patients with brain lesions at normo- and hyperbaric oxygen pressures. J Neurol 217:17-30, 1977

26. Hovda DA, Lee SM, Smith ML, et al: The neurochemical and metabolic cascade following brain injury: moving from animal models to man. J Neurotrauma 12:903-906, 1995

27. Inao S, Marmarou A, Clarke GD, et al: Production and clearance of lactate from brain tissue, 
cerebrospinal fluid, and serum following experimental brain injury. J Neurosurg 69:736-744, 1988 28. Kaku DA, Giffard RG, Choi DW: Neuroprotective effects of glutamate antagonists and extracellular acidity. Science 260:1516-1518 1993

29. Kassissia IG, Goresky CA, Rose CP, et al: Tracer oxygen distribution is barrier-limited in the cerebral microcirculation. Circ Res 77:1201-1211, 1995

30. Katsura K, Asplund B, Ekholm A, et al: Extra- and intracellular pH in the brain during ischemia, related to tissue lactate content in normo- and hypercapnic rats. Eur J Neurosci 4:166-176, 1992

31. Kawamata T, Katayama Y, Hovda DA, et al: Administration of excitatory amino acid antagonists via microdialysis attenuates the increase in glucose utilization seen following concussive brain injury. $\mathbf{J}$ Cereb Blood Flow Metab 12:12-24, 1992

32. Kiening KL, Unterberg AW, Bardt TF, et al: Monitoring of cerebral oxygenation in patients with severe head injuries: brain tissue $\mathrm{PO}_{2}$ versus jugular vein oxygen saturation. J Neurosurg 85:751-757, 1996

33. Krebs EG: Protein kinases. Curr Top Cell Regul 5:99-133, 1972

34. Kuschinsky W, Paulson OB: Capillary circulation in the brain. Cerebrovasc Brain Metab Rev 4:261-268, 1992

35. Landolt H, Langemann H, Mendelowitsch A, et al: Neurochemical monitoring and on-line pH measurements using brain microdialysis in patients in intensive care. Acta Neurochir Suppl 60:475-478, 1994

36. Leninger-Follert E, Lübbers DW, Wrabetz W: Regulation of local tissue $\mathrm{pO}_{2}$ of the brain cortex at different arterial $\mathrm{O}_{2}$ pressures. Pfluegers Arch 359:81-95, 1975

37. Lewelt W, Jenkins LW, Miller JD: Autoregulation of cerebral blood flow after experimental fluid percussion injury of the brain. J Neurosurg 53:501-511, 1980

38. Li RW: Hyperbaric medicine in China, in Kongressbericht 4. Tauchunfaelle, Tauchen und Psyche, Geraetetechnik und hyperbare Oxygenierung. Hannover: Schlueteresche Verlagsanstalt, 1987, pp 149-153

39. López-Barneo J: Oxygen-sensing by ion channels and the regulation of cellular functions. Trends Neurosci 19:435-440, 1996

40. Maas AJR, Fleckenstein W, De Jong DA, et al: Effect of increased ICP and decreased cerebral perfusion pressure on brain tissue and cerebrospinal fluid oxygen tension, in Avezaat CJJ, van Eijndhoven JHM, Maas AIR (eds): Intracranial Pressure VIII. Berlin: Springer-Verlag, 1993, pp 233-237

41. Mahutte CK: Continuous intra-arterial blood gas monitoring. Intensive Care Med 20:85-86, 1994 42. Martin NA, Patwardhan RV, Alexander MJ, et al: Characterization of cerebral hemodynamic phases following severe head trauma: hypoperfusion, hyperemia, and vasospasm. J Neurosurg 87:9-19, 1997 
43. McIntosh TK, Smith DH, Garde E: Therapeutic approaches for the prevention of secondary brain injury. Eur J Anaesthesiol 13:291-301, 1996

44. Menzel M, Rieger A, Roth S, et al: Simultaneous continuous measurement of $\mathrm{pO}_{2}, \mathrm{pCO}_{2}, \mathrm{pH}$ and temperature in brain tissue and sagittal sinus in a porcine model. Acta Neurochir Suppl 71:183-185, 1998

45. Murr R, Stummer W, Schürer L, et al: Cerebral lactate production in relation to intracranial pressure, cranial computed tomography findings, and outcome in patients with severe head injury. Acta Neurochir 138:928-937, 1996

46. Nemes C: Sauerstofftherapie, in Niemer M, Nemes C, Lundgaard-Hansen P, et al (eds): Datenbuch Intensivmedizin. Stuttgart: Gustav Fisher, 1992, pp 84-88

47. Pellerin L, Magistretti PJ: Glutamate uptake into astrocytes stimulates aerobic glycolysis: a mechanism coupling neuronal activity to glucose utilization. Proc Natl Acad Sci USA 91:10625-10629, 1994

48. Persson L, Hillered L: Chemical monitoring of neurosurgical intensive care patients using intracerebral microdialysis. J Neurosurg 76:72-80, 1992

49. Persson L, Valtysson J, Enblad P, et al: Neurochemical monitoring using intracerebral microdialysis in patients with subarachnoid hemorrhage. J Neurosurg 84:606-616, 1996

50. Robertson C: Desaturation episodes after severe head injury: influence on outcome. Acta Neurochir Suppl 59:98-101, 1993

51. Robertson CS, Narayan RK, Gokaslan ZL, et al: Cerebral arteriovenous oxygen difference as an estimate of cerebral blood flow in comatose patients. J Neurosurg 70:222-230, 1989

52. Rockswold GL, Ford SE, Anderson DL, et al: Results of a prospective randomized trial for treatment of severly brain-injured patients with hyperbaric oxygen. J Neurosurg 76:929-934, 1992

53. Roth S, Menzel M, Rieger A, et al: Simultaneous continuous measurement of $\mathrm{pO}_{2}, \mathrm{pCO}_{2}, \mathrm{pH}$ and temperature in brain tissue and sagittal sinus in a porcine model. Br J Anaesth 78 (Suppl):70, 1997 (Abstract)

54. Sachs L: Angewandte Statistik, ed 7. Berlin: Springer-Verlag, 1992, pp 329-332

55. Siesjö BK, Siesjö P: Mechanisms of secondary brain injury. Eur J Anaesthesiol 13:247-268, 1996

56. Tajima A, Nakata H, Lin SZ, et al: Differences and similarities in albumin and red blood cell flows through cerebral microvessels. Am J Physiol 262:H1515-H1524, 1992

57. Valadka AB, Goodman JC, Gopinath SP, et al: Comparison of brain tissue oxygen tension to microdialysis-based measures of cerebral ischemia in fatally head-injured humans. J Neurotrauma 15:509-519, 1998

58. Van Santbrink H, Maas AIR, Avezaat CJJ: Continuous monitoring of partial pressure of brain tissue oxygen in patients with severe head injury. Neurosurgery 38:21-31, 1996 
59. Venkatesh B, Brock THC, Hendry SP: A multiparameter sensor for continuous intra-arterial blood gas monitoring: a prospective evaluation. Crit Care Med 22:588-594, 1994

60. Verweij BH, Muizelaar JP, Vinas FC, et al: Mitochondrial dysfunction after experimental and human brain injury and its possible reversal with a selective N-type calcium channel antagonist (SNX-111).

Neurol Res 19:334-339, 1997

61. Wilson DF, Gomi S, Pastuszko A, et al: Oxygenation of the cortex of the brain of cats during occlusion of the middle cerebral artery and reperfusion, in Erdmann W, Bruley DF (eds): Oxygen Transport to Tissue XVI. New York: Plenum, 1992, pp 689-693

62. Yoshino A, Hovda DA, Kawamata AT, et al: Dynamic changes in local cerebral glucose utilization following cerebral concussion in rats: evidence of a hyper- and a subsequent hypo-metabolic state. Brain Res 561:106-119, 1991

63. Zauner A, Bullock R, Di X, et al: Brain oxygen, $\mathrm{CO}_{2}, \mathrm{pH}$ and temperature monitoring: evaluation in the feline brain. Neurosurgery 37:1168-1177, 1995

64. Zauner A, Bullock R, Young HF: Continuous monitoring of oxygen, $\mathrm{CO}_{2}, \mathrm{pH}$ and temperature in brain tissue using a single sensor. J Neurotrauma 12:468, 1995 (Abstract)

65. Zauner A, Doppenberg EMR, Woodward JJ, et al: Continuous monitoring of substrate delivery and clearance: initial experience in 24 patients with severe acute brain injuries. Neurosurgery 41:1082-1093, 1997

Manuscript received September 24, 1998.

Accepted in final form March 12, 1999.

These studies were supported by National Institutes of Health Grant No. NS 12587. Dr. Menzel was supported by the Leopoldina Award from the German Academy of Nature Sciences and Grant No. LPD1996 from the Federal Ministry of Education Sciences Technology and Development, Germany. Dr. Reinert was supported by the Novartis Foundation, Basel, Switzerland, and the Swiss National Foundation.

Address reprint requests to: Ross Bullock, M.D., Ph.D., Division of Neurosurgery, Medical College of Virginia, Virginia Commonwealth University, P.O. Box 980631, Richmond, Virginia 23298-0631. 